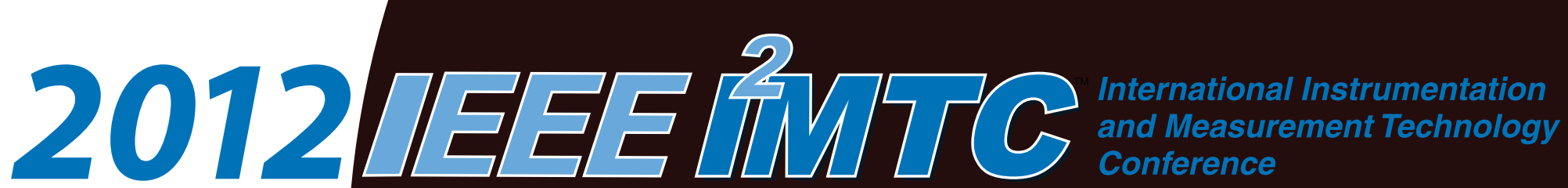

\section{Congress Graz Graz, Austria May 13-16, 2012}

Organized and Sponsored by:

(4). IEEE

\&) $\sqrt{\begin{array}{l}\text { IEEE } \\ \text { instrumentation } \\ \text { \& measurement } \\ \text { society }\end{array}}$

- IEEE Ausrrea SECTON

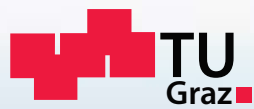

virtual $\Theta$ vehicle

\section{PROCEEDINGS}

(ai) welcome Message

菅 TABIE of CONIENIS

TECHNICAL DAPERS

AUIHOR INDEX

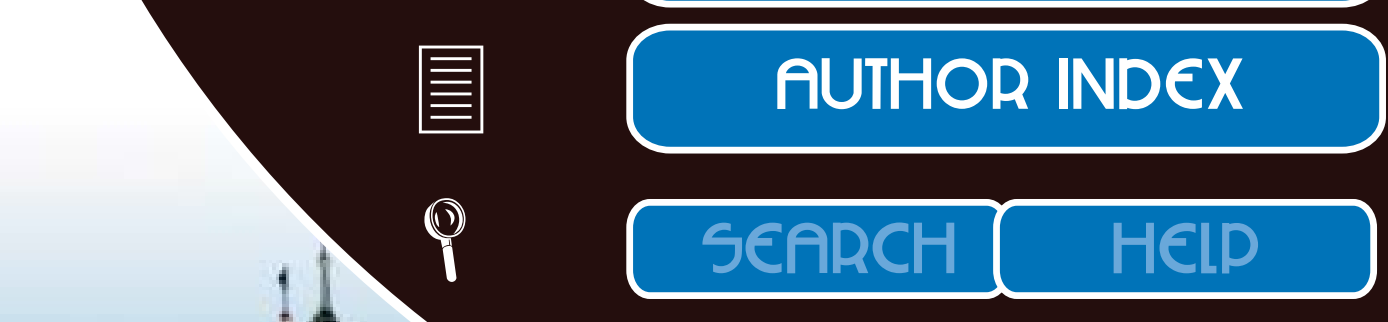

IEEE Catalog Number: CFP12IMT-CDR Technical Support:

ISBN: 978-1-4577-1771-0 Conference Catalysts, LLC

Phone: +1 7853413583

cdyer@conferencecatalysts.com 


\section{(C) 2012 IEEE}

\section{IEEE International Instrumentation and Measurement Technology Conference (I2MTC 2012) Proceedings}

(C) 2012 IEEE. Personal use of this material is permitted. However, permission to reprint/republish this material for advertising or promotional purposes or for creating new collective works for resale or redistribution to servers or lists, or to reuse any copyrighted component of this work in other works must be obtained from the IEEE.

Additional copies may be ordered from:

IEEE Service Center

445 Hoes Lane

Piscataway, NJ 08855-1331 USA

+1800 678 IEEE (+1 800678 4333)

$+17329811393$

+17329819667 (FAX)

email: customer-service@ieee.org

Copyright and Reprint Permission: Abstracting is permitted with credit to the source. Libraries are permitted to photocopy beyond the limit of U.S. copyright law, for private use of patrons, those articles in this volume that carry a code at the bottom of the first page, provided that the per-copy fee indicated in the code is paid through the Copyright Clearance Center, 222 Rosewood Drive, Danvers, MA 01923. Other copy, reprint, or reproduction requests should be addressed to IEEE Copyrights Manager, IEEE Service Center, 445 Hoes Lane, P.O. Box 1331, Piscataway, NJ 08855-1331. All rights reserved. Copyright $\odot 2012$ by the Institute of Electrical and Electronics Engineers, Inc.

IEEE Catalog Number: CFP12IMT-CDR

ISBN: 978-1-4577-1771-0 


\title{
Near-bottom sediment dynamics on highly-protected beaches
}

\author{
The Coastal Ocean Observatory of Barcelona
}

\author{
J. Antonijuan \\ Matemàtica Aplicada IV Dept. \\ EPSEVG-UPC \\ Vilanova i la Geltrú, Spain \\ fina@ma4.upc.edu
}

\author{
J. Guillén, L. López, G. Simarro \\ Institut de Ciències del Mar-CSIC \\ Barcelona, Spain \\ jorge@icm.csic.es; 1lopez@icm.csic.es; \\ simarro@icm.csic.es
}

Abstract- This article presents some preliminary results of the sedimentary dynamics measured during 5 months in Barcelona city beaches (NW Mediterranean). Wave storms, resuspension events and near-bottom sediment fluxes are analyzed in order to characterize the sedimentary behavior of highly-protected beaches.

Keywords-component; coastal zone, sediment transport; currents; storms

\section{INTRODUCTION}

Pocket beaches limited by rocky headlands or artificial structures are singular littoral systems constrained in their cross-shore and longshore sediment flux. They are frequent elements in many coasts and their study is mainly focused on the modification of the platform shape depending on wave conditions. On the contrary, nearshore sediment dynamics is usually oriented to open beaches and previous studies in embayed beaches are scarce. In the framework of the Coastal Ocean Observatory (ICM-CSIC) we plan to develop a longterm measuring program of sediment dynamics in the artificial pocket beaches of Barcelona city in order to unravel specific sediment transport conditions of these beaches and to apply this knowledge to improve the management of this kind of beaches.

\section{THE MONITORING SYSTEM}

The city of Barcelona is located at the Catalan coast (Spain) in the north-western Mediterranean. It is a micro-tidal zone (range about of $20 \mathrm{~cm}$ ) in which waves is the main stirring mechanism controlling coastal evolution. The most energetic storms approach from the east, have a typical duration of a few days, and are often associated with the cyclonic activity in the western Mediterranean. The study site is located in front of the Somorrostro beach, close to the Port Olimpic harbor of the Barcelona city (Fig. 1). A Nortek ADCP AWAC $1 \mathrm{MHz}$ equipped with pressure and temperature sensors, coupled with an OBS (D\&A) turbidity sensor were deployed on a bottom tripod in an upward-looking configuration. The ADCP measured the current speed and direction in $0.5 \mathrm{~m}$ thick layers from the bottom $(0.9 \mathrm{mab})$ to the surface. Waves were measured hourly with bursts of 8.5 minutes at $2 \mathrm{~Hz}$, and currents and turbidity were measured every 10 minutes averaging bursts of 1 minute at $1 \mathrm{~Hz}$. The OBS turbidimeter was located $0.5 \mathrm{mab}$ and it was coupled with an anti-fouling wiper (Hydro-wiper, Zebra-Tech LTD). The tripod was deployed near the pole marking the entrance to the Port Olimpic harbor at $10 \mathrm{~m}$ water depth (Fig. 1). The system was powered from a solar panel installed on the top of the pole. The median grain size of the bottom sediment at the study site is about $225 \mu \mathrm{m}$, with a content of fine sediment (< $63 \mu \mathrm{m})$ lower than $5 \%$.

\section{MEASUREMENTS}

Tripod measurements took place from November 10th, 2010 to April 30th, 2011. The time series allowed us to extract information about wave and current conditions and sediment fluxes during the study in the aforementioned period.

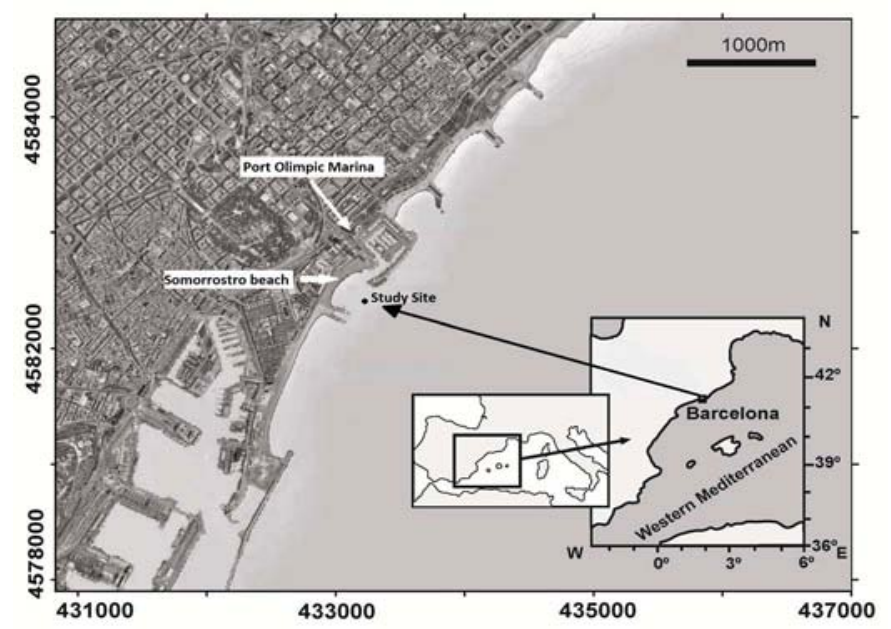

Fig. 1. Map of the western Mediterranean and detailed map of the coastal area in front of Barcelona showing the location of the Somorrostro beach. 


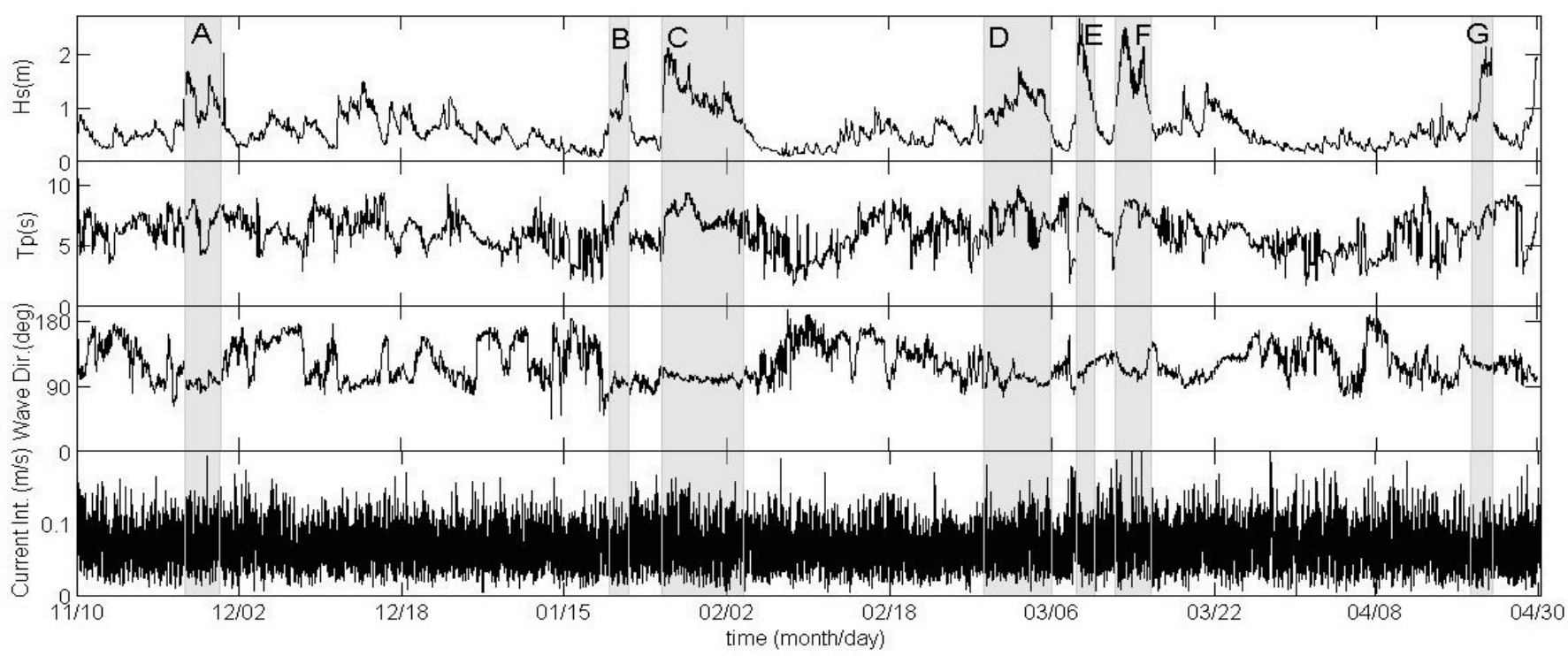

Fig. 2. Wave and current conditions during the study period. From top to bottom: significant wave height, wave peak period, wave mean direction and current intensity at $0.9 \mathrm{~m}$ above the bottom. Shaded regions are the storm events (from A to $\mathrm{G}$ ).

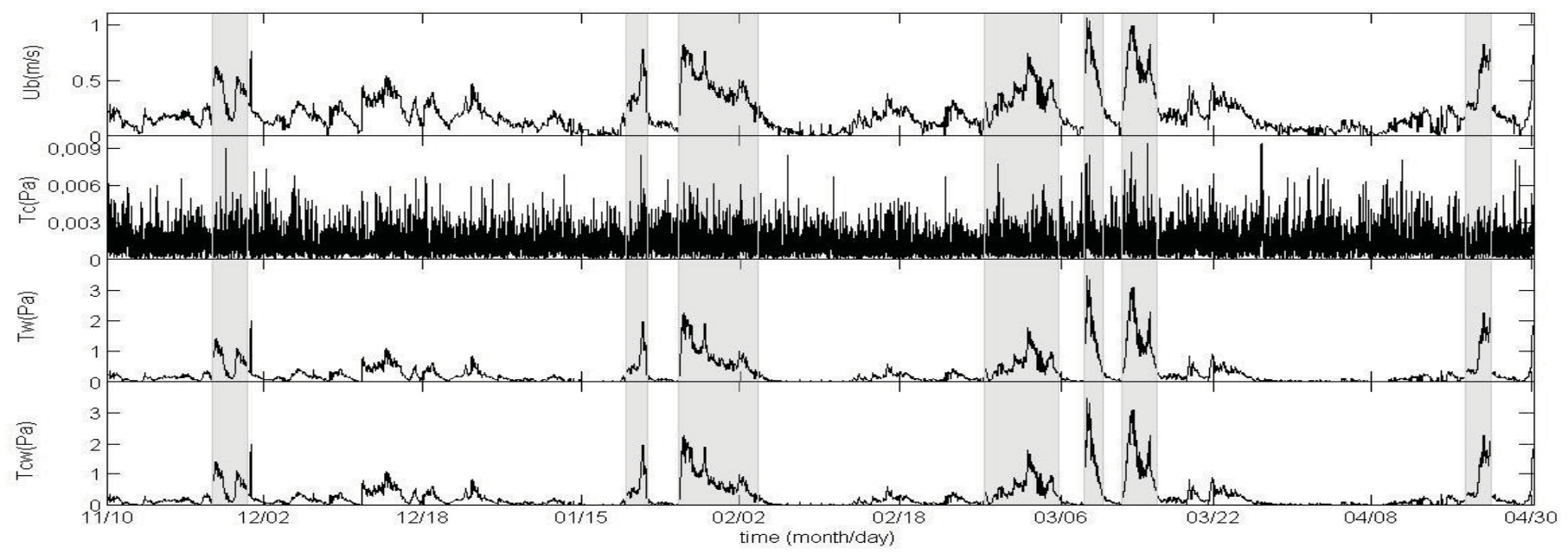

Fig. 3. From top to bottom: Bottom orbital velocity (Ub), current bed shear stress (Tc), wave shear stress (Tw) and combined wave-current bed shear stress (Tcw). (Note the different scale for current bed shear stress)

Seven easterly storms with significant wave height, Hs, over $1.5 \mathrm{~m}$ were identified (see Fig. 2 and Table I). Shaded regions in Fig. 2 show these storms bounded by $\mathrm{Hs}>0.75 \mathrm{~m}$. The event with highest wave $(2.64 \mathrm{~m})$ was the storm beginning on March $8^{\text {th }}$ (storm E in Fig. 2). The wave peak periods reached $9.96 \mathrm{~s}$ and their mean values do not differ significantly between the different storm events.

Interactions between surface waves and the seabed are most conveniently expressed in terms of the wave-induced motion close to the bed (see, e.g., [1]). Near bottom orbital velocities and the components of bed shear stress (current component, $\mathrm{T}_{\mathrm{c}}$, wave component, $\mathrm{T}_{\mathrm{w}}$, and total stress, $\mathrm{T}_{\mathrm{cw}}$ ) are shown in Fig. 3. The bed shear stress was calculated following the methods described in [2] and [3] so as to evaluate sediment resuspension. The total combined wave-current shear stress, $\mathrm{T}_{\mathrm{cw}}$, is well correlated with the near bed orbital velocity, and thus with wave height, since the bottom boundary is dominated by waves $\left(\mathrm{T}_{\mathrm{c}}<<\mathrm{T}_{\mathrm{w}} \sim \mathrm{T}_{\mathrm{cw}}\right)$. The total stress $\mathrm{T}_{\mathrm{cw}}$ reached its maximum value, $3.451 \mathrm{~Pa}$, on March $8^{\text {th }}$ (storm $\mathrm{E}$ ).

Using progressive vectors to represent flow conditions during the survey period, a northeast circulation pattern is stressed at $0.9 \mathrm{~m}$ from seabed (see Fig. 4). In some periods it can be observed reversals in current direction, which happen to match in some cases with storms events. For instance, a longshore current component towards the south is observed at the storm beginning on March $2^{\text {th }}$ (storm D). The progressive vector at $8.9 \mathrm{~m}$ from seabed presents a northeast circulation pattern 

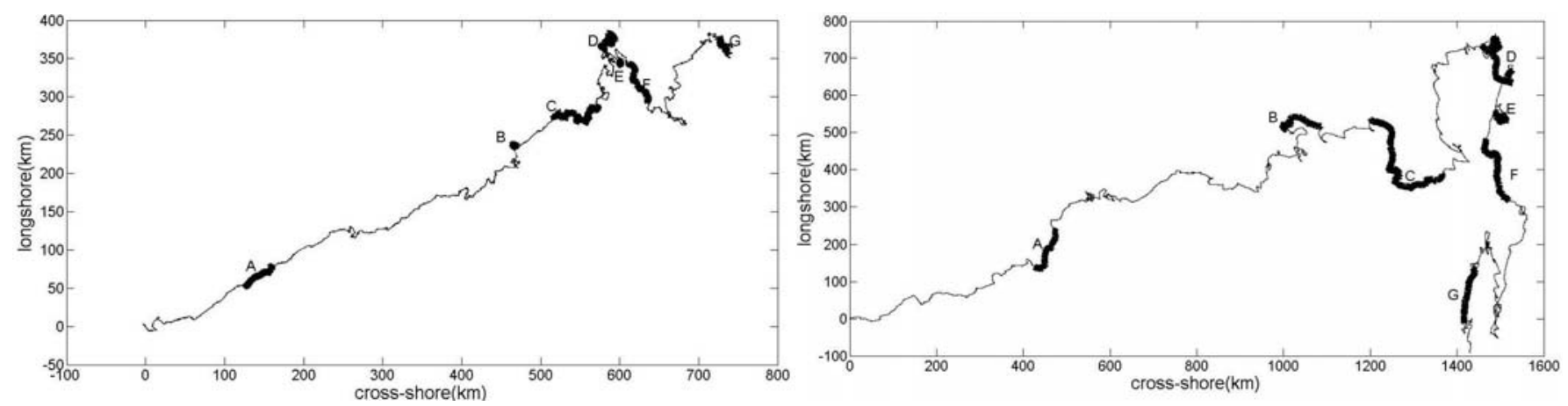

Fig. 4. Progressive vector diagram obtained during the study period at $0.9 \mathrm{~m}$ (left) and $8.9 \mathrm{~m}$ (right) distance from seabed. Starting points are ( 0 , 0$)$ corresponding to their real relative locations. Storms events A to G are in thicker line.

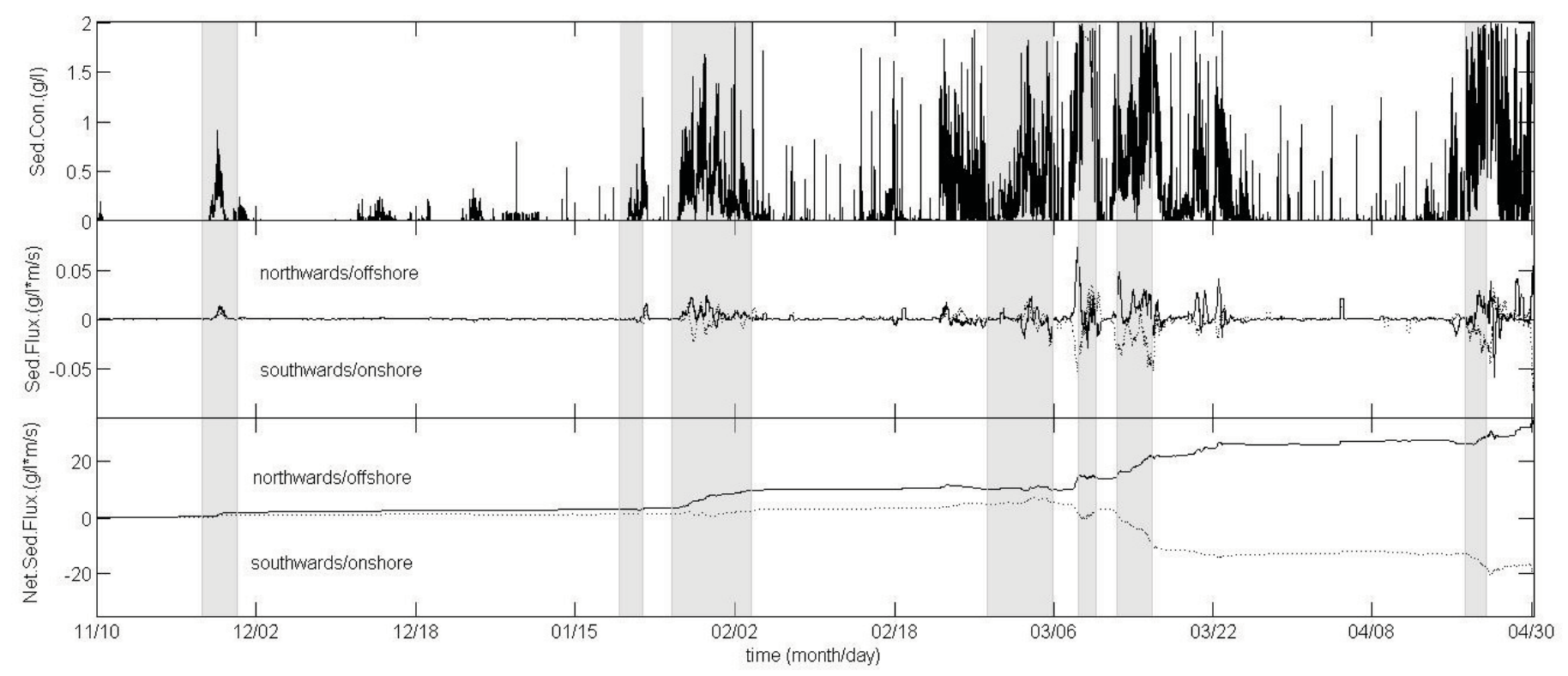

Fig. 5. From top to bottom: Suspended sediment concentration (Sed. Con.); sediment fluxes (Sed Flux) (across-shore in continuous line and alongshore in dotted line) and cumulative net sediment fluxes (Net Sed Flux) (across-shore in continuous line and alongshore in dotted line).

until the end of January (see Fig. 4). From March to April the flow was direct mainly south and parallel to the coast (alongshore).

The measuring range of the turbidimeter was 0-2000 FTU and the transformation to suspended sediment concentration (SSC) was carried out based on an adaptation of the general fit proposed in [4] for the western Mediterranean:

$$
\operatorname{SSC}(\mathrm{mg} / \mathrm{l})=1.74 \mathrm{FTU}-1.32
$$

The peaks in SSC (Fig. 5) are clearly related to the occurrence of storm events, although some of the highest concentration were reached after the peak of the storm (on March 18th SSC $=1.56 \mathrm{~g} / 1$, on April $27 \mathrm{SSC}=1.90 \mathrm{~g} / \mathrm{l}$ ). These concentration peaks suggest a combination of sediment resuspension and advection processes during and after the storm, respectively.

The suspended sediment fluxes can be expressed as the product of the velocity vector (decomposed here into acrossand along-shore components) and the suspended sediment concentration. Fig. 5 shows also the sediment fluxes associated with the flow at $0.9 \mathrm{mab}$. The maximum alongshore and cross-shore transport rates are related to storm activity. If alongshore and across-shore fluxes are integrated over the survey period, they give a cumulative transport (net flux) which presents abrupt changes for both fluxes when storms events took place. During storm events the across-shore flux component comes offshore and the alongshore component is towards the south. Furthermore, the cumulative across-shore component is nearly twice than that alongshore. 


\begin{tabular}{|l|c|c|c|c|c|c|c|}
\hline Storm event & $\mathrm{A}$ & $\mathrm{B}$ & $\mathrm{C}$ & $\mathrm{D}$ & $\mathrm{E}$ & $\mathrm{F}$ & $\mathrm{G}$ \\
\hline \hline Date (month-day-year) & $11-28-10$ & $01-21-11$ & $01-28-11$ & $03-02-11$ & $03-08-11$ & $03-12-11$ & $04-21-11$ \\
\hline Duration (h) & 81 & 46 & 179 & 166 & 45 & 79 & 55 \\
\hline Mean significant wave height $(\mathrm{m})$ & 1.13 & 1.06 & 1.22 & 1.03 & 1.59 & 1.61 & 1.3 \\
\hline Maximum significant wave height $(\mathrm{m})$ & 1.67 & 1.85 & 2.1 & 1.74 & 2.64 & 2.47 & 2.12 \\
\hline Mean wave peak period (s) & 6.85 & 7.77 & 7.27 & 7.03 & 7.4 & 7.5 & 6.93 \\
\hline Maximum wave peak period $(\mathrm{s})$ & 8.8 & 9.96 & 9.34 & 9.91 & 8.86 & 8.82 & 8.36 \\
\hline Mean wave direction (deg.) & 94 & 92 & 100 & 102 & 112 & 114 & 119 \\
\hline Maximum wave direction (deg.) & 112 & 110 & 116 & 146 & 124 & 142 & 131 \\
\hline Mean bottom wave orbital velocity $(\mathrm{m} / \mathrm{s})$ & 0.39 & 0.44 & 0.45 & 0.36 & 0.6 & 0.59 & 0.47 \\
\hline Maximum bottom wave orbital velocity $(\mathrm{m} / \mathrm{s})$ & 0.63 & 0.78 & 0.82 & 0.73 & 1.05 & 0.99 & 0.82 \\
\hline Maximum alongshore velocity at 0.9 mab (m/s) & 0.20 & 0.14 & 0.16 & 0.2 & 0.14 & 0.15 & 0.12 \\
\hline Maximum across-shore velocity at $0.9 \mathrm{mab}(\mathrm{m} / \mathrm{s})$ & 0.19 & 0.17 & 0.2 & 0.17 & 0.2 & 0.22 & 0.18 \\
\hline Mean suspended sediment concentration $(\mathrm{g} / \mathrm{l})$ & 0.12 & 0,14 & 0.35 & 0.28 & 0.65 & 0.64 & 0.89 \\
\hline Maximum suspended sediment concentration $(\mathrm{g} / \mathrm{l})$ & 0.9 & 1.24 & 1.98 & 1.81 & 2 & 1.99 & 1.98 \\
\hline
\end{tabular}

Table I. Characteristics of storm events at the study site.

\section{CONCLUDING REMARKS}

Long-term monitoring of sediment dynamics on a highlyprotected beach reveals frequent resuspension of bottom sediment caused by waves during storms and a dominant nearbottom sediment transport towards offshore. The magnitude of the across-shore sediment transport is higher than alongshore and this could be a differential behavior relative to open beaches.

\section{ACKNOWLEDGMENT}

Data was provided by the Coastal Ocean Observatory of the Institut de Ciéncies del Mar (C.S.I.C.) (http:/coo.icm.csic.es). We thank O. Chic (COO), Servei de Instrumentació (ICM-CSIC) and INNOVA Oceanografía Litoral the support provided in the tripod deployment and data collection. This study was partially supported by the IMNOBE project (CTM2009-11892) and the project
Sistemas Inalámbricos para la Extensión de Observatorios Submarinos (CTM2010-15459). The work of L. López and G. Simarro is supported by the Spanish government through the Formación de Personal Investigador and Ramón y Cajal programs, respectively.

\section{REFERENCES}

[1] P.L. Wiberg, C.R. Sherwood, "Calculating wave-generated bottom orbital velocities from surface-wave parameters," Computers \& Geosciencies, vol. 34, pp. 1243-1262, 2008.

[2] P.L. Wiberg, J.D. Smith, "A comparison of field data and theoretical models for wave-current interaction at the bed on the continental shelf," Cont. Shelf Res., vol. 2, pp. 147-162, 1983.

[3] O.S. Madsen, Sediment transport on the shelf, Lecture Notes, Ralph M. Parsons Laboratory for Water Resources and Hydrodynamics, Department of Civil Engineering, Massachusetts Institute of Technology. Cambridge, USA, 1993.

[4] J. Guillén, A. Palanques, P. Puig, X. Durrieu de Madron and F. Nyffeler, "Field calibration of optical sensors for measuring suspended sediment concentration in the western Mediterranean," Scientia Marina, vol. 64(4), pp. 427-435, 2000. 